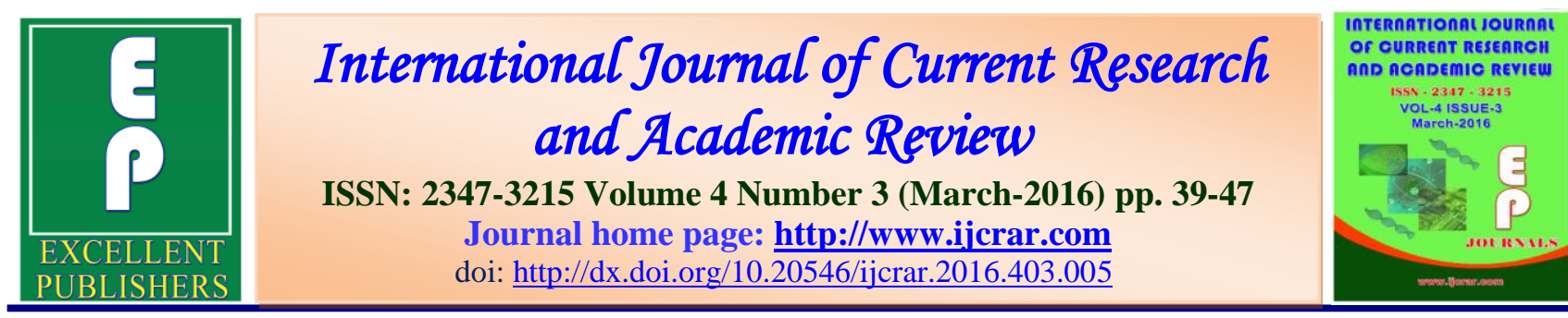

\title{
Biotechnological Applications of Hyperthermophilic Enzymes
}

\section{Raj Kumar Pandey ${ }^{1}$, Anupam Barh ${ }^{2}$, Dinesh Chandra ${ }^{3}$, Satish Chandra ${ }^{3}$, Vishakha Pandey ${ }^{4}$, Pankaj ${ }^{1}$ and Lakshmi Tewari ${ }^{1}$}

${ }^{1}$ Department of Microbiology, G. B. Pant University of Agriculture and Technology Pantnagar, 263145, U. S. Nagar, Uttarakhand, India

${ }^{2}$ Department of Genetics and Plant Breeding, G. B. Pant University of Agriculture and Technology Pantnagar, 263145, U. S. Nagar, Uttarakhand, India

${ }^{3}$ Department of Bíological Sciences, G. B. Pant University of Agriculture and Technology Pantnagar, 263145, U. S. Nagar, Uttarakhand, Indi.

${ }^{4}$ Department of MBGE, G. B. Pant University of Agriculture and Technology Pantnagar, 263145, U. S. Nagar, Uttarakhand, India

\section{*Corresponding author}

\section{KEYWORDS}

Hyperthermophiles,

Thermozymes,

Archaea,

Biotechnological applications.

\section{A B S S T R R A C $\mathbf{T}$}

With the optimal temperatures higher than $80^{\circ} \mathrm{C}$, the hyperthermophilic microbes are now in focus due to their unique enzymatic systems. Initially they found in hot springs of Yellow Stone National Park. The enzymes synthesized by hyperthermophilic bacteria and archaea, also called hyperthermophilic enzymes or sometimes thermozymes are typically thermostable and are optimally active at high temperatures, thus lead to the remarkable heat stability properties for multiple biotechnological and various enzymatic processes. Many literatures reported that the thermozymes share the same catalytic mechanism with their mesophilic counterparts i.e. when cloned and expressed in mesophilic hosts, usually retain their thermal property. This property is very useful because omitting the drawbacks come in enzyme production and cultivation of hyperthermophiles. This review concentrates on the various thermozymes, industrially produced from hyperthermophilic microorganisms. The advantages for various biotechnological processes, the sources and important properties of various hyperthermophilic enzymes are briefly described. Furthermore, their various applications in different processes are also summarized in this review.

\section{Introduction}

The Hyperthermophilic microorgnisms are the microorganisms that thrive at high or very high temperature range, were first described in 1981.They have now been isolated from all types of natural and manmade marine and terrestrial hot 
environments, which were actually discovered in 1967 by Thomas D. Brock from the hot spring of yellow stone national park (Vieille and Zeikus, 2001). They grow optimally at temperatures between 80 and $110^{\circ} \mathrm{C}$, and thus the enzymes from these unusual organisms (so called hyperthermophilic enzymes or broadly thermozymes), usually able to withstand temperatures that would rapidly denature most of the mesophilic or even some thermophilic (optimum growth temperature $=<80^{\circ} \mathrm{C}$ ) proteins and enzymes. Therefore the thermozymes having considerable biotechnological interest over mesophilic or psychrophilic enzymes due to their thermostability which is being associated with resistance to chemical denaturants, performance and extraordinary stability at high temperatures, easy purification by heat treatments after expression, often higher reaction rates due to decrease in viscosity at high temperature and increase in diffusion coefficient of substrate and few or no risks of microbial contamination during fermentation or product formation process (Danson et al., 1996; Adams and Kelly, 1998). Earlier the Thermas aquaticus (source of Taq DNA polymerase) were considered as extreme thermophiles for the commercial enzyme production, but nowadays, Pyrococcus fumarii (a hyperthermophilic archaeon), considered most extreme for biotechnological applications since it grow at up to $113^{\circ} \mathrm{C}$. The major biotechnological advantages of thermophilic and hyperthermophilic enzymes (thermozymes) in various fields, and their few important examples are briefly described in this review.

\section{Applications in Molecular Biology}

\section{DNA Polymerases}

Broadly the DNA polymerases and DNA ligases are the most important enzymes used for the molecular biology experiments. The purification and characterization of $T$. aquaticus Taq DNA polymerase was the revolutionary event in the field of molecular biology since mesophilic polymerases are not able to withstand the temperatures required for the DNA amplification processes (Vieille and Zeikus, 2001; de Miguel Bouzas et al., 2006). Although a few of today's industrial enzymatic processes utilize the thermophilic and hyperthermophilic enzymes, but these enzymes are also having a great importance in the field of basic researches. The Thermophilic DNA polymerases have since been characterized from a number of thermophiles and hyperthermophiles.

The multiple applications of the PCR technology make use of two qualities of these DNA polymerases: Processivity and fidelity. Taq DNA polymerase's high processivity make it the enzyme of choice for sequencing or detection procedures. de Miguel Bouzas et al., 2006 also reported some other thermophilic polymerases (Table 1) are $P$. furiosus Pfu Polymerase, $T$. litoralis Vent polymerase, P. woesei Pwo polymerase; Pyrococcus strain GB-D Deep Vent polymerase, etc. These types of polymerases having the error rates that are much lower than Taq polymerase, owing to their low extension rates and unsuitability for the amplification of long DNA fragments none of them has replaces the use of the $T$. aquaticus Taq enzyme.

\section{Ligases}

Thermophilic DNA ligases are commercially available and optimally active in the range 45 to $80^{\circ} \mathrm{C}$, represent an excellent addition to PCR technology. The genus Thermus having two types of ligases and their dependency on $\mathrm{NAD}^{+}$and $\mathrm{Mg}^{+2}$ or $\mathrm{Mn}^{+2}$ as the metal co-fector is related with 
the fidelity i.e. the $\mathrm{NAD}^{+}$dependent ligases from the Thermus sp. exhibit higher rate of fidelity. These are the model systems for structural and mechanistic study of DNA ligantion due to their high thermostability. These are used for mutation analysis (by oligonucleotide ligation assay), or for gene synthesis (from overlapping oligonucleotides) or for amplification (Kong et al., 1993; Tong et al., 2000).

\section{Proteolytic Enzymes}

Proteases are generally classified in two groups: endopeptidases are the proteases that cleave peptide bonds within the proteinand exopeptidases, which cleave off amino acids from the ends of the protein. Many proteolytic enzymes from hyperthermophilic archaea and bacteria have been identified and these enzymes retain their catalytic activity at higher temperatures, or in the presence of inhibitors like detergents and denaturing substances.

The hyperthemophilic proteases mainly are used for protein $\mathrm{N}$-or C-terminal sequencing. Some thermophilic proteins resist proteolytic digestion at moderate temperatures $\left(20\right.$ to $\left.60^{\circ} \mathrm{C}\right)$ and they only start to unfold and to become sensitive to proteolytic attack above $70^{\circ} \mathrm{C}$ (Voorhorst et al., 1997; Kannan and Mutharasan 1985; Vieille and Zeikus, 2001; de Miguel Bouzas et al., 2006). They have also reported the Thermus Rt41A serine protease (Table 1) which can be used in DNA and RNA purification procedures. In $P$. furiosus protease is used to fragment proteins before peptide sequencing (Table 1).

Numerous thermophilic restriction endonucleases are now commercialized. Most of them, isolated from Bacillus and Thermus strains, are optimally active in the range of 50 to $65^{\circ} \mathrm{C}$.

\section{Applications in Starch Processing}

Starch and sucrose are the primary products of photosynthesis in leaves of most of the plants. It contains two types of polymeric substances of glucose, the amylose and amylopectin. The amylose is linear polymer consisting of units of $\alpha$-glucose linked by $\alpha$ 1, 4 glycosidic bonds. Such chains vary in molecular weight from a few thousand to more than a million. On the other hand in amylopectin, a highly branched polymer of $\alpha$ - glucose, glycosidic linkages joining successive glucose residues with $\alpha-1,4$ chain bonding pattern along with $\alpha-1,6$ bonding at branching points (de Miguel Bouzas et al., 2006; Nelson and Cox, 2008). Industrially, the glucose, maltose, and other oligosaccharide syrups are prepared during the starch hydrolysis by various enzymes (biocatalysts), which replace the use of non eco-friendly, uneconomic and hazardous chemicals. These syrups are then used as fermentation syrups to produce a variety of chemicals (e.g., ethanol, lysine, and citric acid). Furthermore, most agricultural biomass containing starch can be used as a potential substrate for the production of gaseous or liquid fuels, feed proteins, and chemicals by enzymatic process (Afschar and Schaller, 1991; Nigam and Singh, 1995; Niehaus et al., 1999; Vieille and Zeikus, 2001; Gupta et al., 2004). The major enzymes of the starch processing industries are $\alpha$ - amylases (EC 3.2.1.1), that physically liquefies the starch, hydrolyze $\alpha-1,4$ glycosidic linkages of amylase and amylopectins. The end products are glucose, maltose, maltotriose, maltotetrose, maltopentose and maltihexose. The glucoamylases are the enzymes involved in saccharification, are used in the production of glucose syrups (Viktor et al., 2013). The pullulanases (endo 1, 6 glucanases) are responsible for the de-branching of starch in sugar syrups manufacture (Nigam and 
Singh, 1995). Thus the starch bioprocessing usually involves high temperature dependent two steps viz. liquefaction and saccharification. In the liuquifection process, glucose syrups which contain approximately 96\% glucose are produced using pullulanase and glucoamylase in combination, while the maltose syrups contain about 80 to $85 \%$ maltose, are produced using pullulanase and $\beta$-amylase (Crabb and Mitchinson, 1997). The second process i.e. saccharification, involves the conversion of liquefied starch into low-molecular-weight saccharides and ultimately into glucose or maltose. Because the enzymes used in industrial starch processing originate from mesophilic organisms, are only marginally stable at $60^{\circ} \mathrm{C}$, there is a need today for thermostable pullulanases, $\quad \beta$-amylases, $\quad$ and glucoamylases. The $\alpha$-Amylases which operate above $100^{\circ} \mathrm{C}$ at acid $\mathrm{pH}$ values are also targeted for improved processing.

The important thermophilic or hyperthermophilic enzymes involved in starch degradation are listed in (Table 2). Their optimal activities range from 80 to $100^{\circ} \mathrm{C}$ at $\mathrm{pH} 4.0$ to 7.5. An optimal catalyst for starch liquefaction should be optimally active at $100^{\circ} \mathrm{C}$ and $\mathrm{pH} 4.0$ to 5.0 and should not require added $\mathrm{Ca}^{2+}$ for stability. None of the enzymes listed in Table 10 present these combined characteristics (Niehaus et al., 1999; Vieille and Zeikus, 2001; Gupta et al., 2004). Hyperthemophiles typically hydrolyze starch via $\alpha$-amylase and/or an amylopullulanase (table 2). The associated problem with the use of Bacterial $\alpha$ amylases for industrial purposes is they require $\mathrm{Ca}^{++}$for their activity, which, when added to fermentor causes the problems such as blocking of pipes and heat exchangers. The $\alpha$-amylases from hyperthermophiles are the best solution because they are able to work at high temperature and at low $\mathrm{pH}$, and the low $\mathrm{pH}$ inhibits the precipitation of calcium. Thus the utilization of $\alpha$-amylases from Pyrococcus woesei, Pyrococcus furiosus, Thermococcus hydrothermalis are the best option for industrial starch processing (Nigam and Singh, 1995; Vieille and Zeikus, 2001). Thermophilic $\beta$-amylases also improve saccharification by reducing the saccharification time and by increasing the reaction rate at acidic $\mathrm{pH}$. T. maritima $\beta$ amylase could be a good enzyme for testing the impact of high temperatures on the saccharification process. Like $\beta$-amylases, glucoamylases are rare in thermophiles and hyperthermophiles, only a glucoamylase gene has been identified in the $M$. jannaschii genome. The pullulanases hydrolyzing only $\alpha-1,6$-glucosidic linkages (type I pullulanase) and both $\alpha-1,4, \quad \alpha-1,6-$ glucosidic linkages (type II pullulanases or Amylopullulanases) are used as debranching enzymes in starch saccharification. These pullulanases are all optimally active at acidic pHs (table 2). Amylopullulanases purified from the hyperthermophiles $P$. furiosus, ES4, Thermococcus litorails, and $T$. hydrothermailis are active at high temperatures $\left(105\right.$ to $120^{\circ} \mathrm{C}$ ) and at low pHs and they are exceptionally thermostable, they are strong candidates for this process (Gupta et al., 2004; de Miguel Bouzas et al., 2006).

\section{Applications in Bio-ethanol Production}

Lignocellulose is typically non-edible plant material and most abundant biomass from fields or forests that can be utilized for sustainable production of bio-energy, biofuels (such as methane, carbon dioxide) and chemicals, in a bio-refinery which may play a major role in developing the systems, which traditionally produced from the petroleum (Alvira et al., 2010; Sluiter et al., 2010; Saritha et al., 2011; Brinchi et al., 2013). Cellulose is the most abundant and renewable non-fossil carbon source on 
Earth. The bioconversion of cellulosic materials is now a subject of intensive research as a contribution to the development of large scale conversion process beneficial to mankind. Typically embedded in a network of hemicelluloses and lignin, cellulose requires an alkaline pretreatment with high temperature to become accessible to enzyme action, because it typically embedded in a network of hemicelluloses and lignin. One of the main limitations to this three-step process is the low activity (and high cost) of the cellulases used. Since cellulose's alkaline pretreatment is performed at high temperatures, hyperthermophilic cellulases should be the best candidate catalysts for cellulose degradation. Recently the endoglucanases and cellobiohydrolases been characterized in the Thermotogales with the optimum activity range from $95-105^{\circ} \mathrm{C}$. These types of cellulolytic enzymes can be utilized for high temperature requiring cellulolytic reactions for sustainable bioethanol production (Vieille and Zeikus, 2001; Sluiter et al., 2010; Saritha et al., 2011).

Table.1 Thermophilic and Hyperthermophilic Enzymes and their Applications. Table Modified from Vieille and Zeikus, 2001; Bouzas et al., 2006

\begin{tabular}{|c|c|c|c|}
\hline S.No. & Enzyme and source & Application of enzyme & Properties of enzyme \\
\hline 1. & $\begin{array}{l}\text { T. aquaticus Taq DNA } \\
\text { polymerase }\end{array}$ & PCR technologies & $\begin{array}{l}\text { Optimal activity at } 75^{\circ} \mathrm{C}, \\
\text { pH } 9.0\end{array}$ \\
\hline 2. & $\begin{array}{l}\text { a. Carboxydothermus } \\
\text { hydrogenoformans DNA } \\
\text { polymerase } \\
\text { b.Thermus thermophilus DNA } \\
\text { polymerase }\end{array}$ & $\begin{array}{l}\text { Reverse transcription-PCR (for } \\
\text { performing cDNA synthesis by } \\
\text { reverse transcription) }\end{array}$ & $\begin{array}{l}\text { optimal activity as } 60- \\
70^{\circ} \mathrm{C}\end{array}$ \\
\hline 3. & $\begin{array}{l}\text { P. furiosus Pfu DNA ligase } \\
\text { Thermus DNA ligase }\end{array}$ & $\begin{array}{l}\text { Used for DNA ligation at high } \\
\text { temperatures }\end{array}$ & $\begin{array}{l}\text { Both are active at } 45- \\
80^{\circ} \mathrm{C}\end{array}$ \\
\hline 4. & $\begin{array}{l}\text { S. solfataricus DNA binding } \\
\text { proteins }\end{array}$ & $\begin{array}{l}\text { Used in DNA-DNA hybridization for } \\
\text { reduction of time and enhancing the } \\
\text { specificity of reaction. }\end{array}$ & $\begin{array}{l}\text { ATP-independent, } \\
\text { homology dependent } \\
\text { DNA annealing at } 60^{\circ} \mathrm{C}\end{array}$ \\
\hline 5. & $\begin{array}{l}\text { Thermus strain } \\
\text { Serine protease }\end{array}$ & $\begin{array}{l}\text { DNA and RNA purifications; cellular } \\
\text { structures degradation prior to PCR. }\end{array}$ & $\begin{array}{l}\text { Optimal activity at } 90^{\circ} \mathrm{C}, \\
\text { pH 8.0; }\end{array}$ \\
\hline 6. & $\begin{array}{l}P . \text { furiosus Methionine } \\
\text { aminopeptidase }\end{array}$ & $\begin{array}{l}\text { Cleavage of the } \mathrm{N} \text {-terminal Met in } \\
\text { proteins }\end{array}$ & $\begin{array}{l}\text { Optimal activity at } 85- \\
95^{\circ} \mathrm{C}, \mathrm{pH} 7.0-8.0 .\end{array}$ \\
\hline 7. & $\begin{array}{l}\text { S. solfataricus } \\
\text { Carboxypeptidase }\end{array}$ & $\begin{array}{l}\text { C-terminal sequencing Broad } \\
\text { specificity }\end{array}$ & - \\
\hline 8. & $\begin{array}{l}\text { T. neapolitana alkalin } \\
\text { phosphatase }\end{array}$ & Enzyme-labeling applications & $\begin{array}{l}\text { Optimal activity at } 85^{\circ} \mathrm{C} \text {, } \\
\text { pH 9.9; }\end{array}$ \\
\hline
\end{tabular}


Table.2 Some Examples of Thermophilic and Hyperthrmophilic Enzymes used in Starch Processing. Table is Modified from Niehaus et al., 1999; Vieille and Zeikus, (2001)

\begin{tabular}{|c|c|c|c|}
\hline S.N. & $\begin{array}{l}\text { Starch hydrolyzing } \\
\text { Enzyme }\end{array}$ & Source of enzyme & Enzymatic properties \\
\hline 1 & $\alpha$ - amylase & $\begin{array}{l}\text { Desulfurococcus mucosus } \\
\text { Pyrococcus sp. } \\
\text { Staphylothermus marinus } \\
\text { Thermococcus profundus } \\
\text { Dictyoglomus thermophilum } \\
\text { Thermotoga maritime }\end{array}$ & $\begin{array}{l}\text { Optimum enzyme activities in } \\
\text { between } 90-100^{\circ} \mathrm{C} \text {. } \\
\text { Optimum } \mathrm{pH} \text { ranges from } 4.0- \\
6.0 \text {, (For Thermotoga } \\
\text { maritima, optimum pH is 7.0). }\end{array}$ \\
\hline 2 & Pullulanase & $\begin{array}{l}\text { Bacillus flavocaldarius } \\
\text { Thermotoga maritima } \\
\text { Thermus caldophilus } \\
\text { Fervidobacterium pennavorans }\end{array}$ & $\begin{array}{l}\text { Optimal activities in between } \\
75-90^{\circ} \mathrm{C} \text {, pH range } 5.5-6.3 \text {. }\end{array}$ \\
\hline 3 & Amylopullulanase & $\begin{array}{l}\text { Desulfurococcus mucosus } \\
\text { Pyrococcus furiosus } \\
\text { Thermococcus celer } \\
\text { Thermococcus litoralis } \\
\text { Thermococcus hydrothermalis } \\
\text { Thermoanaerobacter ethanolicus }\end{array}$ & $\begin{array}{l}\text { Optimal activity at } 90-120^{\circ} \mathrm{C} \\
\mathrm{pH} \text { range from } 5.0-6.5\end{array}$ \\
\hline 3 & Glucoamylase & $\begin{array}{l}\text { Clostridium thermosaccharolyticum } \\
\text { Methanococcus jannaschii } \\
\text { Thermoanaerobacterium } \\
\text { thermosaccharolyticum }\end{array}$ & $\begin{array}{l}\text { Optimal activity in between 50- } \\
70^{\circ} \mathrm{C}, \mathrm{pH} \text { range } 4.0-5.5 \text {; }\end{array}$ \\
\hline 4 & $\beta$-Amylase & $\begin{array}{l}\text { Thermotoga maritima } \\
\text { Thermoanaerobacterium } \\
\text { Thermosulfurigenes }\end{array}$ & $\begin{array}{l}\text { Optimal activity in between } 75- \\
95^{\circ} \mathrm{C} \text {, optimum pH range is } \\
\text { from 3.5-6.0 }\end{array}$ \\
\hline 5 & Glucoamylase & $\begin{array}{l}\text { Clostridium thermosaccharolyticum } \\
\text { Methanococcus jannaschii } \\
\text { Thermoanaerobacterium } \\
\text { Thermosaccharolyticum }\end{array}$ & $\begin{array}{l}\text { Optimal activity at } 50-70^{\circ} \mathrm{C} \text {, } \\
\text { pH ranges from } 4.0-5.5 .\end{array}$ \\
\hline 6 & $\alpha$-Glucosidase & Thermoanaerobacter ethanolicus & $\begin{array}{l}\text { Optimal activity at } 75^{\circ} \mathrm{C}, \mathrm{pH} \\
5.0-5.5\end{array}$ \\
\hline
\end{tabular}

\section{Paper Pulp Bleaching}

The paper industry utilizes the pulping process for the removal of most of the lignin. Generally pulping carried out by giving hot-alkali treatment of the wood fibers. The remaining lignin is removed by a multistep bleaching process by chlorine and its compounds at high temperature. The chlorinated lignin derivatives generated by this process constitute a major environmental problem. Chen et al., 1997 reported that more than 2 million tons of chlorine and its derivatives are used annually in U.S. for pulp bleaching.

The amount of chemical used-and, therefore, the resulting pollution-can be reduced if the paper pulp is pretreated with enzymes. Hyperthemophilic hemicellulases (mainly xylanase) have only been characterized in the Thermotogales. Xylanase treatment opens up the cell wall structure, thereby facilitating lignin removal in subsequent 
bleaching stages (Voorhorst et al., 1997; Alvira et al., 2010; Vieille and Zeikus, 2001).

Hyperthermophilic xylanases from Thermotoga, Dyctioglomus, Sulfolobus, Pyrococcus and Pyrodictium were isolated with optimal temperatures above $90^{\circ} \mathrm{C}$. Many hyperthermophilic xylanases have been cloned and successefully expressed in Escherichia coli (de Miguel Bouzas et al., 2006). Other hemicellulases (e.g., $\alpha$ glucuronidase, $\quad \beta$-mannanase, $\alpha$-L-arabinofuranosidase, and galactosidases) have been shown to contribute to the enzymatic treatment of the pulp. reported the most thermostable laccase enzyme from Thermus thermophilus HB27. The organism produces $53 \mathrm{kDa}$ intracellular laccase which can be utilized in pulp bleaching. Feasibility of applying this enzyme in pulp bleaching has not been investigated, but still it was successfully utilized in bleaching of wheat straw pulp (Vieille and Zeikus, 2001).

\section{Other Applications of Hyperthermophilic Enzymes}

Some enzymes used in pharmaceuticals are horseradish peroxidase, alkaline phosphatase, and glucose phosphate dehydrogenase. The thermostable alkaline phosphatase recently characterized from Thermotoga neapolitana is highly active at high temperatures. Methylesterases and lyases are pectinolytic enzymes degrade the pectin, is a branched heteropolysaccharide abundant in plant tissues. (Kannan and Mutharasan 1985; de Miguel Bouzas et al., 2006). These enzymes are widely used in the food industries due to their catalytic and stability properties compatible with industrial needs (Vieille and Zeikus, 2001).

Chitin (a linear $\beta-1,4$ homopolymer of $N$ acetylglucosamine) is also an abundant carbohydrate in the biosphere.Chitnase could be used for the utilization of chitin as a renewable sourceand for the production of oligosaccharides as biologiacally active substances. A few thermophilic chitinase have been characterized. Their potential for the economically competitive chitin degradation process remains to be tested (Afschar and Schaller, 1991; Vieille and Zeikus, 2001; Gupta et al., 2004). Animal feedstock production processes include heat treatments that inactivate potential viral and microbial contaminants. Using thermophilic enzymes (i.e., arabinofuranosidase and phytase) in feedstock production would enhanced digestibility and nutrition of the feed while allowing the combination of heat treatment and feed transformation in a single step (Nigam and Singh, 1995; Niehaus et al., 1999; Vieille and Zeikus, 2001; Sluiter et al., 2011).

\section{Conclusion}

The major problem in most of the industrial enzymatic processes is to compromise between difficult working conditions such as high temperature and the stability of the working enzyme(s). Various enzymes as mentioned in this review from hyperthermophilic microorganisms offer a great solution for various industrial processes carried out at high temperatures. The applications of hyperthermophilic enzymes result from the discovery that molecular biology and biochemical studies such as protein purification and characterization are facilitated by the cloning and expressing of genes from hyperthermophiles in mesophilic hosts. Thus the development of molecular tools together with biotechnological research should lead to the future availability of new hyperthermophilic enzymes to meet all types of industrial demands for a developed future. 


\section{References}

Adams, M.W., Kelly, R.M. 1998. Finding and using hyperthermophilic enzymes. Trends in Biotechnol., 16(8): 329332.

Afschar, A.S., Schaller, K. 1991. Production of acetone and butanol from starch by continuous bioprocess. J. Biotechnol., 18: 255-264.

Alvira, P., Tomás-Pejó, E., Ballesteros, M., Negro, M.J. 2010. Pretreatment for an efficient bioethanol production process based on enzymatic hydrolysis: A review, Biores. Technol., 101: 4851-4861.

Brinchi, L., Cotana, F., Fortunati, E., Kenny, J.M. 2013. Production of nancrystalline cellulose from Lignocellulosic biomass: Technology and Apllications. Carbohydrate Polymers, 94: 154-169.

Chen, C., Adolphson, R., Dean, J.F.D., Eriksson, K.L., Adams, M.W.W., Westpheling, J. 1997. Release of lignin from kraft pulp by a hyperthermophilic xylanase from Thermatoga maritime. Enzyme Microbial Technol., 20: 39-45.

Crabb, W.D., Mitchinson, C. 1997. Enzymes involved in the processing of starch to sugars. Tibtech., 15: 49-352.

Danson, M.J., Hough, D.W., Russell, R.J., Taylor, G.L., Pearl, L. 1996. Enzyme thermostability and thermoactivity. Protein Engi., 9(8): 629-630.

De Miguel Bouzas, T., Barros-Velázquez, J., Gonzalez Villa, T. 2006. Industrial applications of hyperthermophilic enzymes: a review. Protein Peptide Lett., 13(7): 645-651.

Gupta, R., Gupta, N., Rathi, P. 2004. Bacterial lipases: an overview of production, purification and biochemical properties. Appl.

Microbiol. Biotechnol., 64: 763-781.

Kannan, V., Mutharasan, R. 1985. Ethanol fermentation characteristics of Thermoanaerobacter ethanolicus. Enzyme Microb Technol., 7: 87-89.

Kong, H., Kucera, R.B., Jack, W.E. 1993. Characterization of a DNA polymerase from the hyperthermophile archaea Thermococcus litoralis. Vent DNA polymerase, steady state kinetics, thermal stability, processivity, strand displacement, and exonuclease activities. J. Biol. Chem., 268(3): 1965-1975.

Nelson, D.L., Cox, M.M. 2008. Principles of Biochemistry, $5^{\text {th }}$ Ed, pp. 245.

Niehaus, F., Bertoldo, C., Kahler, M., Antranikian, G. 1999. Extremophiles as a source of novel enzymes for industrial applications. Appl. Microbiol. Biotechnol., 51: 711-729.

Nigam, P., Singh, D. 1995. Enzymes and microbial system involved in starch processing enzyme. Microb. Technol., 17: 770-778.

Saritha, M., Arora, Anju, Lata. 2011. Biological pretreatment of lignocellulosic substrates for enhanced delignification and enzymatic digestibility. Ind. J. Microbiol.

Sluiter, A., Hames, B., Ruiz, R., Scarlata, C., Sluiter, J., Templaton, D., Crocker, D. 2010. Determination of structural carbohydrates and lignin in biomass, Technical Report NREL/TP-51042618, National Renewable Energy Laboratory, Golden, CO.

Tong, L.J., Moss, G.A., Pickering, T.D., Paewai, M.P. 2000. Temperature effects on embryo and early larval development of the spiny lobster Jasus edwardsii, and description of a method to predict larval hatch times. 
Marine Freshwater Res., 51(3): 243248.

Vieille, C., nZeikus, G.J. 2001. Hyperthermophilic enzymes: sources, uses, and molecular mechanisms for thermostability. Microbiol. Mol. Biol. Rev., 65(1): 1-43.

Viktor, M.J., Rose, S.H., Van Zyl, W.H., Viljoen-Bloom, M. 2013. Raw starch conversion by Saccharomyces cerevisiae expressing Aspergillus tubingensis amylases. Biotechnol. Biofuels, 36: 167-177.
Voorhorst, W.G., Warner, A., De Vos, W.M., Siezen, R.J. 1997. Homology modelling of two subtilisin-like proteases from the hyperthermophilic archaea Pyrococcus furiosus and Thermococcus stetteri. Protein Engi., 10(8): 905-914.

Zeeman, S.C., Kossmann, J., Smith, A.M. 2010. Starch: Its metabolism, evolution, and biotechnological modification in plants. Ann. Rev. Pl. Biol., 61.

\section{How to cite this article:}

Raj Kumar Pandey, Anupam Barh, Dinesh Chandra, Satish Chandra, Vishakha Pandey, Pankaj and Lakshmi Tewari. 2016. Biotechnological Applications of Hyperthermophilic Enzymes. Int.J.Curr.Res.Aca.Rev.4(3): 39-47. doi: http://dx.doi.org/10.20546/ijcrar.2016.403.005 